\title{
Aeschylus, Sophocles, Euripides and Menelaos Shaping the Significance of Electra Myth: A Dialogue Between Arts Tatiana GOLBAN ${ }^{1}$, Atanas KARAÇOBAN ${ }^{2}$
}

\begin{abstract}
The present study focuses on the tragic heroine, Electra, who rose to prominence in the Athenian dramas of the fifth-century BC, particularly in Aeschylus's Choephori, Sophocles's Electra and Euripides's Electra, but this enigmatic figure continued to stir the imagination of the artists of the subsequent generations to the extent of making its presence memorable not only in literary texts but also in visual arts and music. This paper attempts to reveal the ways in which Electra myth has delighted and inspired various artists by stressing out the peculiarities of this myth that never seems to go out of fashion. It can also be observed that Electra's figure, even sculpted in marble severity, continues to arouse both pity and admiration in her quest and demand for justice as well as her attempts to re-establish the religious, moral and societal values.
\end{abstract}

Keywords

Electra Myth

ancient tragedy

fine arts

Electra and Orestes marble sculpture

About Article

Received: 24.02.2021

Accepted: 29.04.2021

Doi:

10.20304/humanitas.886011

\section{Elektra Mitinin Tekrar Yaratılmasında Eshilos, Sophokles, Euripides ve Menelaos: Sanatlararası Bir Diyalog}

$\ddot{O} z$

Bu çalışma, Eshilos'un Adak Sunucuları, Sophokles'in Elektra ve Euripides'in Elektra adlı oyunları başta olmak üzere, milattan önce beşinci yüzyılda yer alan Atina dramalarında ön plana çıkan trajik kahraman Elektra'ya odaklanmaktadır. Bu gizemli figür varlığını sadece edebi metinlerde değil görsel sanatlar ve müzik alanında da unutulmaz kılacak şekilde sanatçıların hayal gücünü etkilemeye devam etmektedir. Bu çalışma, asla çağdışı olmayan Elektra mitinin özelliklerini vurgulayarak söz konusu mitin çeşitli sanatçılar için hangi yollarla ilham kaynağı olduğunu ortaya koymaya çalışmaktadır. Bunun yanı sıra, mermer sertliğinde şekillendirilmiş Elektra figürünün bile adalet arayışıyla birlikte dini, ahlaki ve sosyal değerlerin yeniden tesisi çabalarında hem acıma hem de hayranlık duygusu uyandırmaya devam ettiği gözlemlenmektedir.

\section{Anahtar Sözcükler}

Elektra miti

antik trajedi

güzel sanatlar

Elektra ve Orestes mermer heykelleri

\section{Makale Hakında}

Geliş Tarihi: 24.02.2021

Kabul Tarihi: 29.04.2021

Doi:

10.20304/humanitas.886011

\footnotetext{
1 Prof. Dr., Namik Kemal University, Faculty of Arts and Sciences, Department of English Language and Literature, Tekirdag/Turkey, tgolban@nku.edu.tr, ORCID: 0000-0002-7860-0992

2 Lecturer, Ankara Haci Bayram Veli University, Faculty of Fine Arts, Ankara/Turkey, atanaskaracoban@yahoo.com, ORCID: 0000-0001-7028-7535
} 


\section{Introduction}

The myth has always been a perpetually alive, never ending source of images, symbols and themes which inspire the production of distinct works of art. While some myths reveal the creation, the beginning of all things, or explain how something started to exist, some others are of a more communal nature, having a social and religious mission which is set to establish certain didactic and sacred parameters for the human being. According to Frog, myths can be viewed in terms of "emotionally invested thinking models" (Frog, 2015, p. 38). While approaching some of the myths as identity bearing stories, Frog stresses out that the symbols belonging to a particular myth may be viewed as elements in a vaster matrix of mythology and they become "emotionally invested symbols because they are socially recognized as being meaningful to people in powerful ways, whether they are so deeply established that they function as unconscious assumptions or they are actively contested within or across communities" (Frog, 2015, p. 38).

This might be the case of Electra myth, traditionally regarded as part of the mythological cycle of the Atrides, but which becomes later an autonomous, identity bearing literary myth with its own symbolic saturation which refers to a fundamental situation for the human condition. Certain symbols from the broader mythological matrix of the house of Atreus become emotionally invested to the extent of their revision and metamorphoses, leading naturally to the creation of another myth. This tendency towards transformation becomes stronger especially with the process of secularisation in the ancient society, as the literary production becomes one of the privileged domains for the representation of the mythical discourse. In this respect, André Dabezies explains that

here more than elsewhere one must take account of the quality of the formal expression and of the authors' personalities, their introduction of transformations, their ability to project themselves into the narrative or to integrate into it a particular element of contemporary life. All these transformations could act on the oral recitation of the primitive myth, but in literary myths they are multiplied indefinitely, to the point of dismembering and sometimes almost completely obscuring the original dramatic shape (Dabezies, 1992, p. 966).

Regardless of the authors' intention for transformations and variations in Electra myth, the symbolic matrix of this mythical scenario is preserved, as it represents a system of symbols which is accompanied by the constructions and conventions for their combination that seem to be pertinent to a certain language, culture and religious framework. The myth of Electra originates in the ethno-religious myth of Atrides; it emerges from and is eternally connected to it, and Aeschylus's Choephori plays an enormous role in the introduction and 
reverberation of the name of Electra (see Golban 2004, Golban 2006). However, though the myth of Electra originates in the ethno-religious myth of Atreus family, it becomes fully consolidated as a literary myth due to its original representations by Sophocles, Euripides, Eugene O'Neill, and others who respect the initially established pattern of the mythical matrix but also recognize a new vitality in certain symbols of this myth and, by becoming emotionally invested, they broaden the quality of their signification, transforming, re-casting, and even substituting some elements from the original myth.

\section{The Representation of Electra Myth in Ancient Greek Tragedies}

Electra myth is clearly a case when literature begets its own myths (see Golban 2004, Golban 2006). Though Homeric epos never mentions Electra, there is a reference in the Odyssey to Clytemnestra and Aegisthus's adultery, Agamemnon's triumphant homecoming from the Trojan War, followed by his murder by his wife and his stepbrother upon his return home, and also to Orestes's duty to avenge his father's death, neglecting, however, the aspect of matricide, which will be extensively explored by the later poets. This proves once again the relationship of the myth to literature, namely epic, and although critics compare the epic to the romance and consider the latter to be the next developmental step of the former towards the rise of the novel, "it is more often agreed that the place of the epic in literary history is taken over by drama" (Golban, 2018, p. 82).

Mentioned for the first time in Hesiod's Catalogue of Women, the name of Electra might have also been brought up by the poets preceding the great tragedians who, judging from some short remaining fragments, depicted such motifs of the myth as Iphigenia's sacrifice, Agamemnon's murder, Orestes's vengeance and the matricide. It is the undeniable merit of Aeschylus's Choephori, the second play of the trilogy Oresteia, Sophocles's Electra and Euripides's Electra to have carved the name of Electra into the memory of posterity and created Electra myth.

According to a primary etymology, the name "Electra" means light, brilliance, clarity, purity, energy, and this interpretation transforms Electra into a herald of truth, a symbol of rebellion, a quest for and re-establishment of justice. Some other interpretations refer to $a$ electra, which signifies deprived of nuptial bed, that is a virgin, pure and infallible, but it also means futile in all her attempts and enterprises. The dark streak which emerges from the complicity to matricide and vengeance confer a dose of ambiguity that leads to a flexibility of mythical symbols and to a wide thematic diversity for the artists who focus on Electra. This ambiguity is stressed out by José Pedro Serrain his claim that "Electra is a sombre, nocturnal, 
lunar character, whose gestures are laced with funeral traces of death. Her voice breaks out in threatening cries and demanding vengeance, obscure outpourings that express the ever-open wound of pain in revolt" (Serra, 2015, p. 90).

As an identity-bearing myth, which splits from broader matrix of the myth of Atrides but becomes an autonomous myth as a result of the revision of the some emotionally invested elements, Electra myth proves extraordinary elasticity, which is sustained primarily by the powerful inner conflicts experienced by this mythical character and by actions which are triggered by strong emotional ambiguity which allows a different significance with each artistic variation. The never-ending fluctuations of the symbolic matrix and themes prevent the creation of a single possible interpretation of this myth.

The socio-cultural and religious aspects of antiquity and modernity find their expression in Electra myth as an independent system, within the larger mythical matrix of the Atrides due to its constitutive thematic elements, among which an alienated character who suffers enormously, violent action, curse, acknowledged guilt, search for harmony and lost values. Even though in each representation this myth attempts to re-establish the religious and societal values through a gruesome punitive act and the acceptance of the consequences of the committed act, it fails to produce a solution to the existent crisis, strengthening instead the dimension of a tragic human existence and the human capacity to suffer as a cathartic experience which aims at re-evaluation and the reinforcement of the ethical individual and communal values.

The artistic expressions of Electra myth stress out the violent act, rebelliousness, and the excessive desire to dominate, the very instinctive drives which are frequently depicted in tragedy. René Girard, who refers to Oedipus myth in his mythic-archetypal analysis of violence, claims that patricide and incest

serve to conceal the sacrificial crisis far more effectively than they reveal it. To be sure, they manage to express both aspects of the crisis, both reciprocity and forced similarities; but they do so in a way that strikes terror into the beholder and suggests that they are the exclusive responsibility of a particular individual (Girard, 1979, p. 76).

Following Girard's statement, it can be observed that in the case of Electra myth matricide could be viewed as an attempt to conceal an existential crisis, and though at first glance it might seem to be the responsibility of one particular individual, Orestes' in this case, it extends to the life of all community, and it is Electra's unrepeated heroic luminosity and her determination that contribute to the exposure of this societal crisis. The input of the tragic 
poets is immense, as their artistic works have depicted in an aesthetical manner the human desire to commit violence, especially as a mimetic act. According to Girard,

Tragedy envelops all human relationships in a single tragic antagonism. It does not differentiate between the fraternal conflict of Eteocles and Polyneices, the father-son conflict of Alcestis or Oedipus the King, the conflict between men who share no ancestral ties, such as Oedipus and Tiresias. (...) Tragedy tends to restore violence to mythological themes. It in part fulfils the dire forebodings primitive men experience at the sight of twins. It spreads the pollution abroad and multiplies the mirror images of violence (Girard, 1979, p. 65).

It is surprising to see how much insight the great tragic poets of antiquity possessed when they reflected the mirror images of violence when depicting the myth of Atrides or Electra myth. Aeschylus, Sophocles and Euripides represented the matricide and the need for justice, depicting various hypostasis of Electra, with her need for atonement and her tragic pathos. Although Aeschylus in his Oresteia focuses mostly on Agamemnon's murder and the necessary punitive act carried out by Orestes - his contribution on the whole emphasising the familial curse which dooms the House of Atreus, the disturbance of harmony created by Clytemnestra's and Aegisthus's criminal act and the atonement of for this act with an equally horrifying crime - his merit is especially connected with bringing Electra out of anonymity and conferring her a role in the punitive act. Though mostly passive of all ancient literary representations, Aeschylus's Electra is the driving force in the act of vengeance, since the ever-insecure Orestes hesitates much when the decision to commit matricide should be made. Electra is the one who reveals the injustice and the need to re-establish order and communal values.

Another peculiarity of Aeschylus's text consists in his depiction of the status of female characters, the women of the Atrides who acquire strongly individualized personalities, especially when compared to the representation of male characters of the trilogy. Thus, although aiming at the glorification of the tragic male heroes, like the victorious Agamemnon or his son Orestes, whose sacred duty renders him heroic, ironically these masculine heroes are somehow surpassed by the strength and determination of Aeschylean female characters. This perspective is stressed out especially by the representation of an ignoble Aegisthus, marginalized and overshadowed completely by the dominance of the formidable Clytemnestra. It is worth noting that the tremendous strength of Clytemnestra is presented from the very beginning of Aeschylus's trilogy, when the watchman comments: "That woman - she manoeuvres like a man", pointing out that her ferociousness is totally atypical to women in her community (Aeschylus, 1977, p. 103).Surely, he is far from the intention of depicting 
the female characters as tragic heroines, especially since some qualities of femme fatale are revealed in them. As a sister of the archetypal femme fatale Helen of Troy, Clytemnestra bears the characteristics of a destroyer; she is a ferocious woman who, although known for her extreme beauty, possesses an excessive desire to dominate, which exceeds any maternal, nourishing and soothing qualities conventionally attributed to women.

Being one of the Atrides women, Electra inherits some of the features of Clytemnestra and even though Electra hates and despises her mother enormously, there are some undeniable characteristics which she inherits from her. One can easily detect already in Aeschylus's Choephori Electra's ferocious nature, expressed in her desire for revenge, her rebelliousness and an aspiration to dominate and destroy, inherent in her features of a femme fatale, expressed through her incessant persuasion of Orestes to commit the punitive crime. Ironically, the qualities which are rendered heroic in Electra by the later artists are also the ones inherited from her mother. We refer to Electra's resilience, tenacity and determination to act, which are mostly visible in Aeschylus's Clytemnestra, and, though alarming at times, these qualities prove to be mostly fascinating in their display of ambiguity. Electra's vagueness is also suggested by the interplay between light and darkness. Dressed completely in black as a traditional mourner, her clothes allude also to her inner darkness which stems from her grieving and from her desire for revenge. Electra is still trying to fight her inner dark streak with the hope of Orestes's arrival and act:

ELECTRA: I see pure Artemis bristle in pity - yes, the flying hounds of the Father slaughter for armies... their own victim ... a woman trembling young, all born to die (...) Cry, cry for death, but good win out in glory in the end (Aeschylus, 1977, p. 108).

Electra believes that this darkness can be illuminated by Orestes' vindictive act, thinking that this sacred duty would not only drag her from this obscurity, but will drive away the pollution which was brought upon Argos by Clytemnestra's crime. Instead, as it can be seen from the trilogy, it adds even more to the existent ambiguity. Despite of the dark aspects of Electra's personality, her princely pride, the cult of the idealized parent, as well as the acute sense of justice prepared the stage for Aeschylean character to become one of the most complex and fascinating tragic heroines in later dramatic representations.

Sophocles is the poet who confers to Electra the status of a tragic heroine and establishes forever the parameters of Electra myth. In his play Electra, the poet changes the role of his protagonist: her personal condition is raised to the highest standards of suffering, grieving and humiliation, and her extreme desire for revenge seems to be her only 
consolation. Electra's ferociousness contrasts greatly with the submissiveness to the master, expressed by her sister Chrysothemis. Sophocles underlines Electra's personality especially by the means of contrast. To Chrysothemis's obedience, he opposes Electra's lamentation and rebelliousness, which are emboldened by the excessive hatred for the murderers of her father. The most striking opposition is created between the protagonist Electra and Clytemnestra, especially visible in Electra's concern with the well-being of community versus Clytemnestra's extreme meanness and unlawfulness. Surprisingly, while displaying the differences between these two women, Sophocles makes sure that their agonizing conflict reflects what Girard calls "the mirror images of violence" (Girard, 1979, p.65). The scholar explains that the more the verbal violence is prolonged, "the more likely it is to culminate in a violent mimesis; the resemblance between the combatants grows ever stronger until each presents a mirror image of the other" (Girard, 1979, p.47).

Girard's words point out the fact that violence begets violence, and, regardless of initial dissimilarity between the combatants, a striking resemblance emerges as a result of the mimetic acts. The unbridled passion, the desire to kill and an excessive hatred, which characterise Clytemnestra fuse into Electra's character and when Clytemnestra's death-cry is heard, Electra shocks the audience by her primal exclamation: "Hit her a second time, if you have the strength!” (Sophocles, 2001, p. 106). The display of her astounding cruelty continues in the moment of Aegisthus' confrontation, Electra crying:

Don't let him speak by the gods!

Brother —no speechmaking now!

When a human being is so steeped in evil as this one

what is gained by delaying his death?

Kill him at once. Throw his corpse out

for scavengers to get.

Nothing less than this

can cut the knot of evils

inside me (Sophocles, 2001, p. 110).

With such a gloomy display of the protagonist's nature one would wonder what truly makes Sophoclean character a tragic heroine, the remarkable resemblance between Electra and Clytemnestra being unsettling. However, Sophocles suggests that from the moral point of view Electra's tragic stance dominates Clytemnestra's. The dirty old rags in which Electra is dressed point to her pride and moral integrity, as she is unwilling to bow in front of the 
unlawful rulers. Contrary to the vanity of Clytemnestra and Chrysothemis who find delight in beautiful clothes and objects of luxury, Electra seems to value only the memory of her father and brother. The urn that presumably contains the ashes of the dead Orestes becomes the most valuable object for the heroine. Sophocles employs tragic irony in order to increase the sympathy of the audience towards his protagonist and also to raise the awareness to her tenderness. Apparently a ruthful creature who seeks revenge at all cost, Electra is still extremely vulnerable and capable of immense love, which is vivid in the recognition scene between the siblings.

This dynamic and decisive woman possesses also an amazing inner power and volition to carry over the act of justice. As a keeper of Atrides' virtues and traditions, she reveals resilience and tenacity even when all odds are against her. Her determination to seek vengeance, though originating in her private reasons, states her priority for the needs of the community. This is the reason why Sophocles focuses on the myth of Electra, as this is one of the few myths in which not only the salvation of the individual integrity is at stake but also the re-establishment of the universal equilibrium (implied by the respect of the cult of the dead) and the communal welfare (which would prevent the tyrannical and unlawful rule of Argos by Aegisthus and Clytemnestra). The tragic poet makes sure to celebrate the act of Orestes and Electra:

CHORUS: O seed of Atreus:

you suffered and broke free,

you took aim and struck;

you have won your way through

to the finish! (Sophocles, 2001, p. 111)

The final words by the chorus indicate a kind of passage from darkness into light, and though Electra's ambiguity is increased by her role of an accomplice to the crime, she remains an exemplary character through her ability of pursuing higher moral goals. Her embracement of suffering, sacrifice and tragic existence lead her to an inevitable hamartia, but her capacity to make the true moral choices, which, although perceived as doubtful at times, always reveal her demand for justice, responsibility, and communal welfare.

Sophocles does not simply create a new version of the myth of Atreus family. His play establishes the myth of Electra as a literary fact through his alteration of the original myth and the manipulation of some symbolic situations from the larger mythical matrix. In his tragedy Electra is the driving force of the action, the one who determines the accomplishment of the 
action, and this places her into a liminal space that accentuates her tragic stance. In this respect, Serra aptly mentions that

Electra is a misfit and transgressor, living in a kind of limbo, on the threshold between the living and the dead, between the feminine and masculine world, and the gynaecium, inside the palace, and polis, the public space of political action. Despised and exiled in her own home, wrapped in despicable robes, unworthy of her royal condition, Electra wanders in the indefinable space of the palace entrance, a space it is impossible to belong to and in which, unfit to inhabit as it is, she wanders like a nuance to be tolerated (Serra, 2015, pp. 93-94).

This displacement of Electra is depicted well by Euripides in his eponymous play, in which the heroine is placed within the fluid boundaries of a no man's land, stripped off her paternal hearth, exiled to the city's outskirts, married to a labourer, but still a virgin, neither royal daughter nor a true wife, captured within struggle and suffering which drain her off, but unwilling to assuage or end it. This dislocation in which Euripides places his protagonist is further extended, for his Electra is not simply deprived of her place at home and of her royal status, but she becomes estranged from her own gender as well. In Euripides's Electra, his female character is bereft of traditional attributes of feminine beauty, like face, hair and clothes, a fact which reinforces her liminal state. Though referred to in Sophoclean version, Electra's tattered robes gain a different significance in this text; together with her tear-stained face and her short-cropped hair, her dirty clothes intend to suggest her extreme humiliation, but also her refusal to beautify herself, which is made clear by her rejection of any offers from the chorus members. At first glance, Electra's appearance might be associated with the fifthcentury Athenian status of mourning and servility, which would be pertinent in relation to Electra's role in the myth. However, the motif of sordid clothes is further developed in the play in relation to Electra's physical appearance, in a manner in which Electra is both linked to and contrasts Clytemnestra. In the agon of the play, Electra confronts her mother, despising her for preening her golden hair in front of a mirror in the absence of her husband (vs. 10701073) and for her concern with material luxury, which Clytemnestra enjoys to display, namely the Asian slaves that accompany her, the Idaean robes and the golden accessories, all used to reinforce her splendour and femininity (vs. 314-318). Richard Hawley truly argues that in Euripides's play

[b]oth women are given a concern for spectacle. Both women want to arouse emotions in those who see them: for Electra pity and shock, for Clytemnestra awe. Clytemnestra arrives as an ideal upper-class wife: concerned to manage her attendants well, striving to wear fine 
clothes and appear supremely feminine. By contrast, Electra denies her femininity at every juncture: tearing her face, wearing dirty rags, cropping her hair (Hawley, 1997, p. 49).

Electra's denial of femininity is clear from her refusal to take part in the conventional feminine joys, like dance and clothes, but especially from her cropped hair, by which she seems to sever any bond that she might have with her mother. Her hair is shaved as a sign of mourning, but, at the same time, as an acknowledged desire to resemble her admired father, an act which might bear resemblance to a barbarian ritual prior to war, which displays manly valour and masculinity. Electra's place at the threshold between the masculine and feminine is further suggested by the water jug that she carries on her head during her first appearance on the stage. A reminiscence of the urn of ashes of Sophoclean Electra, the jug, which traditionally is used by slave women who labour for the household, in Electra's case, it becomes an object of expressing her revolt, a refusal to become weak. Contrary to some scholars' opinion that this object indicates Electra's humiliation and humbleness (see Serra 2015), we believe that Electra's decision to carry the jug is a part of her display of strength, a heroic attitude which gives her an opportunity to reveal her determination to assume her duty and carry it till the end, regardless of her reduced position.

The blurred boundaries between the feminine and masculine realms in Euripidean play are further suggested by the attitude toward heroic action, Electra being the only character in the play displaying courage, revolt and determination, whereas the other characters are rarely heroic, standing on the verge of anti-heroic. Orestes is deprived of any heroic features, as he is constantly overwhelmed by doubt in all his actions, while the moment of Aegisthus's murder by Orestes who comes on his tiptoes and stabs his enemy from behind, especially after a ritual of sacrifice is performed, divests Agamemnon's son of any dignity and grandeur.

Euripides modifies the mythical scenario to the extreme; in his play, Electra is the only one who shows valour and determination in carrying out the vindictive act, while Orestes is somehow emasculated by showing the lack of any initiative and courage. Out of this impasse emerges the need of a partnership, in which Electra becomes the co-participant and a partner in the punitive action, but instead of celebrating the rise of a new heroine, Euripides reveals how one blinded by accumulated hatred develops a distorted sense of justice and exhibits shocking brutality and malice. The echoes of Aeschylus's Clytemnestra are detected in Euripides' Electra, the ferocious nature, the demand for revenge and especially mischievousness of this protagonist being easily recognizable from the way the siblings 
ensnare and slaughter Clytemnestra, a moment which reminds the audience of Agamemnon's entrapment and murder in Oresteia.

Euripides stresses out the fluidity of the boundaries of such contradictory passions as love-hate, delight-suffering, pride - humility, and his protagonist reveals the complexity of human psyche and the unfathomable depth of the unconscious shown through illogical actions and distorted ethical issues. The ambiguity of his Electra, who manages to be both fallen and morally superior, has continuously fascinated the artistic imagination of the upcoming generations. Electra's place at the threshold between private-public, duty-desire, justiceinjustice, heroic-mundane and sacred-profane has led to an unprecedented freedom of representation of Electra myth.

\section{The Representation of Electra Myth in Visual Arts}

As a mythic discourse, Electra myth is transformed and manipulated in various modes of artistic expression, strengthening its significance through each variation of its symbolic matrix and gaining a different quality of signification in relation to every artistic convention, culture and religious mindset. It should be worth noting that most representations of Electra myth in visual arts focus on Aeschylus's Electra, the most popular motif being Electra as chief mourner at Agamemnon's tomb. The ancient vase paintings which pick up Electra myth mostly bring to the centre of attention, as Cecilia Luschnig specifies, "the meeting of Electra and Orestes, and most of these depict their meeting at their father's tomb" (Luschnig, 2015, p. 220). Though Aeschylus's Electra is considered to be the most passive artistic representation of Greek Antiquity, his protagonist is still engaged in the act of bringing libations to Agamemnon's tomb and is a driving force who persuades Orestes to commit the punitive act, whereas the visual artists have reduced Electra's role considerably, refusing to give her any action, and her portrayal is solely as sitting or standing at her father's tomb among grave objects which express the preferences of the artists' culture and conventions (Taplin, 2007, pp. 96-97).

A surprisingly active role is given to Electra in a spectacular marble sculpture, dating back to the first-century BC Rome, created by the Greek artist Menelaos, born in South Italy and known as a prominent sculptor and engraver. Believed to be a scholar who had a great impact upon Varro and Pliny the elder, but due to the lack of certainty surrounding his work, this artist is surprisingly ignored by the academic research. His marble sculpture represents the two siblings standing in front of Agamemnon's tomb, being engaged in a deep mourning. Apparently, this sculpture depicts the favoured motif of a loyal daughter in her grieving; 
however, the portrayal by the ancient artist seems to defy all the paradigmatic conventions regarding the form of the body, male-female proportions of the body and also those of beauty, known by the time of representation.

Inheriting from the Egyptians a culture of idealised, well-proportioned human bodies, the Greeks improved the craft of sculptural human figures by infusing more life, movement and a sense of moral potential that transcended the static forms of their predecessors. As Joseph Manca explains, "[r]eflecting a philosophical search for the ideal, the sculptors aimed at achieving timeless beauty" (Manca, 2014, p. 7). In the manner the Greek philosophers considered such issues as ideal Good, the perfect justice or the nature of ideal republic, the artists set the purpose of attaining the representation of the perfect human forms. The frequent preference of sculptors for a naked, young male body expresses the Greek fascination with athleticism and military prowess but it also reveals their sexual appreciation. An example for this quest for ideal is reflected in the famous kouros, a monumental sculpture of a naked male youth, which was frequently erected as standing and mourning, having the function of funerary commemorations of a deceased (Squire, 2019, p. 35). Its female counterpart, kore, was clothed, respecting the conventions of the time, but still set to represent youth and ideal beauty. Despite the little variations in proportions, facial expression and hair, "the kouros embodied a more or less symmetrical idea of balance, poise, and equilibrium" (Squire, 2019, p. 35). Gradually, the sculptures which reveal the Athenian preoccupation with ideals of the perfect body elaborated more the movement of the body and the emotion, but constantly preserved the balance of weight, proportion and rhythm.

Following the great changes brought by the fall of the Greek city-states and the loss of their independence, there emerged "a changed perception of one's place in the universe, and it is hardly surprising that novel artistic results occurred in all of the visual arts" (Manca, 2014, p. 8). The Greek colonies in the Italian peninsula prepared the territory for the development of the figural arts. The Etruscans clearly adopted the Greek traditions of the figural modes and with the spectacular rise of the Romans from a small city-state to the great empire, it led to the creation of new Roman sculptural products which preserve the classical Greek set of ideal proportions, but is combined with a new Roman emphasis in portraiture, with a special emphasis on the character and moral strength, especially of those who were socially or politically promising.

The flourishing of the Roman portraiture was closely related to the political and ideological changes in the empire, providing extraordinary opportunities for the artists to 
create the images of the emperors and public leaders and display them in such public spaces as on triumphal arches, towering columns, or at the baths. The Romans were fascinated with the Greek works of art and philosophy and the sculptors did not hesitate to imitate the Greek fashion. Willing to stay as memorable as their predecessors, the Romans of all social classes attempted to adorn most public sites with sculptural figures, displaying objects of art even in the private spaces of their urban homes. Moreover, "[the] Romans developed a vigorous sculptural tradition surrounding the rituals of death and mourning, and their funerary portraits and sarcophagus reliefs provide a rich legacy of artistic history" (Manca, 2014, p. 9).

Though the Roman monuments gradually started to employ multiple styles, revealing a more fluid spectrum of artistic possibilities, there also was a great tendency to create largescale figural funerary monuments used to commemorate the departed ones. Among the most important components for commemoration was the emphasis placed on the exemplary acts by the deceased for the living, on the durability of one's memory after death, as well as on the portrait of the dead which should contribute to the preservation of the memory. Josephine Shaya explains that "a monument is not just something to record the past, but something to reconstruct the past with. Monuments offer simplified meanings to complicated events" (Shaya, 2013, p.83). It appears that through the creation of these monuments, the Romans did not simply attempt to commemorate the glorious past but also to manipulate ideologically their future.

It is worth mentioning that in parallel with the honorific portraits statues which commend contemporary personalities, there were statues erected to commemorate famous ancestors, together with historical and mythological figures. In this respect, Jane Fejfer claims that " $[t]$ he role of ancestors which initially had related to the personal, became more closely linked with the communal values of the city: ancestors were represented in monumental and public form as the summi viri in the Forum of Augustus" (Fejfer, 2008, p. 71).

Menelaos's marble sculpture of Electra and Orestes can be placed within this Roman tradition of death and mourning, which commemorates and commends exemplary character and behaviour. In the artist's quest for self-affirmation and visibility, his choice of these two mythological figures denotes that, especially Electra is viewed as an embodiment of grief and loyalty. Dwelling upon a series of iconic moments of Electra myth, the artist creates a visual representation of Electra's anguish in a manner in which it inevitably interacts with Greek art, but at the same time, establishes a dialogue with the texts of the great Greek tragedians. The image of Menelaos's sculpture of Electra and Orestes would be revelatory in this sense. 


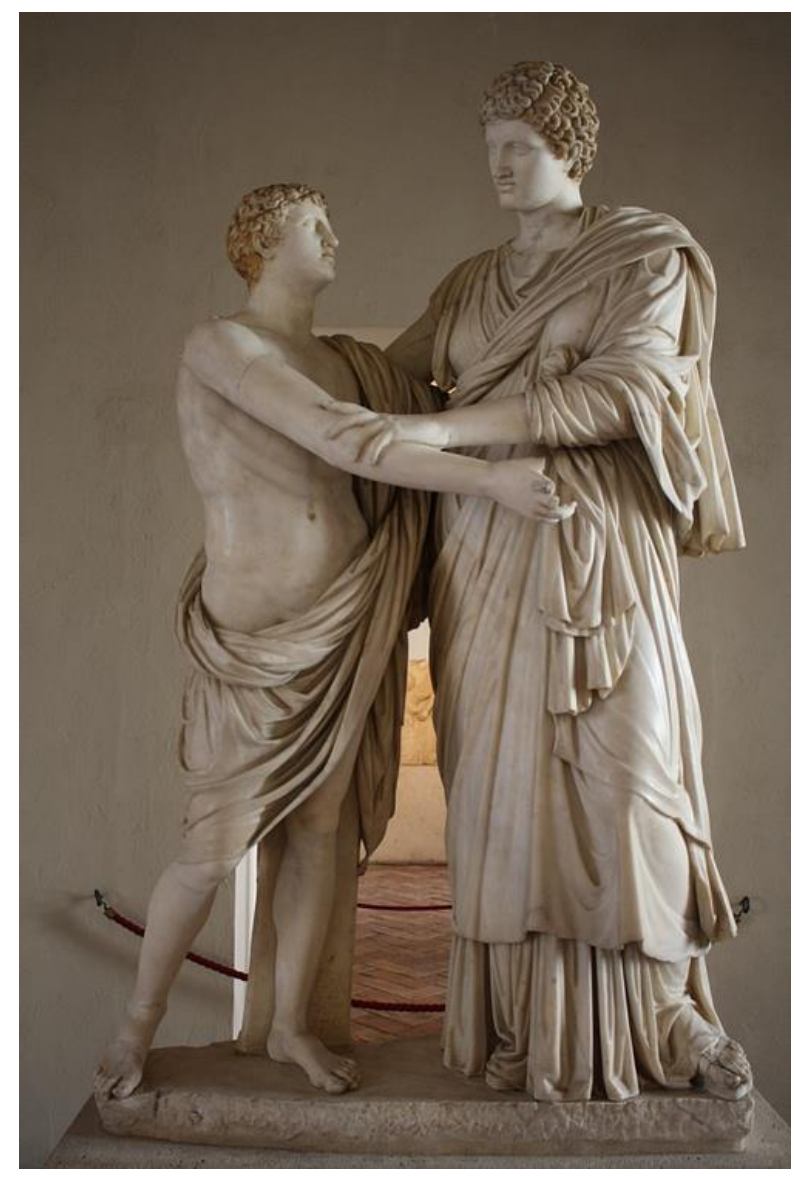

Figure 1. Marble life size sculpture of Electra and Orestes from front by Menelaos 130-29 (BC). Museo Nazionale Romano

The first thing that attracts our attention is the height of the statue (Figure 1), which, although reveals a life-size expression, it may surprise the viewer by the inversion of the masculine and feminine bodily proportions. Departing from the traditional naturalism of the Greek art, Menelaos allows himself to fictionalize the bodily proportions of Electra and Orestes, displaying a shocking height and massiveness for Electra, which contrasts to Orestes's gauntness and pettiness. It reveals the artist's desire to alter the proportions of these characters' bodies in order to attain the purpose of his sculpting. Speaking of disabling bodies, Nicolas Vlahogiannis asserts the following:

Each measure changes the body to move it closer to the prevailing aesthetic ideal of a particular social group; each serves as a means of communication, providing symbolic information about the bearer's personal interests, social position, relationship and selfdefinition (Vlahogiannis, 1997, p. 13).

The above statement implies that the modifications of Electra's and Orestes's bodies express some psychological, moral and emotional realities, and their changed shapes denote some cultural codes of knowledge through which the artist and the Roman world are 
perceived. Menelaos's disregard to specific proportions of the masculine and feminine bodies reveals his redefined role of individual in his community. Rather than viewing Electra's immensity as a socially ascribed abnormality, the sculptor tries to emphasise the attitude of ambivalence regarding this heroine, which is expressed in mythology and in Greek tragedy. Menelaos's Electra expresses the liminal space, which characterises this mythological figure, between the masculine and feminine, heroic and mundane, private and public. Sculpted in marble severity, Electra's imposing proportions suggest her status of power which is attained by her ability to rebel, mourn and stay loyal to the memory of her father. Though marginalized, debased and disempowered in her paternal house, Electra is capable to defy all odds and empower herself even in her unnatural state. Electra's size may also suggest, the excess of her suffering which confers to her the status of the privileged seeker of justice. Defying the norm of the perfect body, Menelaos creates his heroine with a sense of perfection which does not emerge from the conventional expectations of balance and harmony, but from her moral and emotional qualities as a chief mourner, as a loyal daughter and sister, and as a keeper of familiar and communal values. The grandeur of the tragic heroine is expressed in the sculptural aesthetics of the Roman artist. Reconnecting in visual terms the idea of Electra as a tragic heroine and his sculptural aesthetics of severity and durability, Menelaos creates his character as an embodiment of morality and justice which are attained primarily through suffering. Following the attitude of the stoic philosophers, the artist gives voice to suffering, which becomes appealing in both aesthetic and moral terms. Electra's suffering is further expressed through her cropped hair, a sign of her refusal to beautify herself, a striking image which suggests once again the heroine's ambiguous nature.

Of the two siblings depicted by Menelaos, Electra definitely dominates the visual space of the marble sculpture, her large figure dressed in draperies covering her immense body, while her facial expression reflecting an enormous anxiety, lament, but also a surprisingly feminine need to protect her family members. This sculpture might have been inspired mostly by Euripides's play Electra, as Orestes is represented in Electra's protective embrace, his petit figure suggesting a degree of effeminacy and weakness which definitely challenges the accepted social order and heroic ideal. A contrast is created between Electra's totally clothed body and Orestes's partially covered body. While Electra's drapery clothing might suggest her solemnity, conveying the weight of her feelings, Orestes's robe partially covers and partially unveils his vulnerability. Although muscular and beautiful, Orestes's body becomes somehow disabled when compared to the too masculine and immense body of his sister. Vlahogiannis explains that the "disabled are thus the Other for the able-bodied, 
challenging the norms of society, and simultaneously defining and being defined by the cult of the heroic body" (Vlahogiannis, 1997, p. 23).

The engagement with the body reflected in Menelaos's marble sculpture indicates the shift in focus which takes place in the ancient Roman society. Rather than seeking to express masculine and feminine superficial beauty, the artist finds beauty in a moralising purpose, in exemplary character and behaviour. Menelaos's Electra and Orestes represent some significant mythological figures whose symbolic or traditional attitudes were altered in order to fit some definite social functions, such as the commemoration of the dead, keeping the familial and communal values alive as well as the quest for justice.

\section{Conclusion}

Our study attempts to present Electra myth as originating in literature and also as expressed in various forms of art. This myth emerges in the literarised myth of the house of Atreus, but it becomes fully consolidated as a myth of individual essence, having a communal, moral and religious mission, in the literary works of Aeschylus, Sophocles, and Euripides. The tragic poets' creative interpretation of the myth, with the emphasis on some didactic and sacred parameters for the human being, has brought to the establishment of a certain permanence of Electra myth in the literary discourse but also in fine arts, proving extraordinary vitality of its symbolic matrix with each interpretation. Though mostly productive in antiquity, with scarce artistic representations from Renaissance to the nineteenth century, due to its extraordinary flexibility Electra myth emerges from its lethargic oblivion in the twentieth century and continues to express the anxieties, doubts, and fears in all forms of artistic expression. 


\section{References}

Aechylus. (1977). Oresteia (R. Fagles, Trans.). London: Penguin Books.

Dabezies, A. (1992). Fromprimitive myths to literary myths. In P. Brunel (Ed.), Companion to literary myths, heroes and archetypes (pp. 960-967). London: Routledge.

Fejfer, J. (2008). Roman portraits in context Vol. 2. New York: Walter de Gruyter.

Frog,M. (2015). Mythology in cultural practice: A methodological framework for historical analysis. RMN Newsletter, 10, 33-57.

Hawley, R. (1997). The dynamics of beauty in classical Greece. In D. Montserrat (Ed.), Changing bodies, changing meanings: Studies on the human body in Antiquity (pp. 3754). London: Routledge.

Girard, R. (1979). Violence and the sacred. London: John Hopkins University press.

Golban, T. (2004). Ancient and modern hypostases of Electra myth. Dumlupinar Universitesi Sosyal Bilimler Dergisi,11, 41-52.

Golban, T. (2006). Electra myth - The myth of inter-human determinism. Dumlupinar Universitesi Sosyal Bilimler Dergisi,15, 181-190.

Golban, P. (2018). A History of the Bildungsroman: From Ancient Beginnings to Romanticism. Newcastle upon Tyne: Cambridge Scholars Publishing.

Luschnig, C. E. (2015). Electra. In Brill's companion to the reception of Euripides (pp. 90103). Boston: Brill Publishing.

Manca, J., Manca, J., Bade, P. \& Costello, S. (2014). 1000 sculptures of genius. New York: Parkstone International Press.

Serra, J. P. (2015). Electra, the voice of Hades. In A. R. Fernandes (Ed.), The power of form: Recycling myths (pp 90-103). London: Cambridge Scholars Publisher.

Shaya, J. (2013). The public life of monuments: The SummiViri of the Forum of Augustus. American Journal of Archaeology,117(1), 83-110.

Sophocles. (2001). Electra. New York: Oxford University Press.

Squire, M. (2019). The art of the body: Antiquity and its legacy. Oxford: Oxford University Press.

Taplin, O. (2007). Pots and plays. Interactions between Tragedy and Greek Vase-painting of the fourth century BC. Los Angeles: The J. Paul Getty Museum. 
Golban, T. \& Karaçoban, A. (2021). Aeschylus, Sophocles, Euripides and Menelaos Shaping the significance of Electra myth: A dialogue between arts. Humanitas, 9(18), 112-129.

Vlahogiannis, N. (1997). Disabling bodies. In D. Montserrat (Ed.), Changing bodies, changing meanings: Studies on the human body in Antiquity (pp. 13- 36). London: Routledge. 